\title{
EFFECT OF COLLAR DIAMETER AND LIFTING PERIOD ON SHOOT BIOMASS PRODUCTION OF TEAK (TECTONA GRANDIS LINN. F) STUMPS
}

\author{
K. A. Nkyi ${ }^{1}$, W. Oduro ${ }^{2}$ and O. O. Gyedu ${ }^{3}$ \\ ${ }^{1}$ Silviculture and Forest Management, Faculty of Renewable Natural Resources, KNUST, Kumasi \\ ${ }^{2}$ Wildlife and Range Management, Faculty of Renewable Natural Resources, KNUST, Kumasi \\ ${ }^{3}$ Forestry Services Division, Forestry Commission, Ministry of Lands, Forestry and Mines, Ghana.
}

\begin{abstract}
:
The effects of collar diameter and lifting period on shoot biomass production of Teak (Tectona grandis Linn. F) stumps were investigated during the 2006 dry season on the research farm of Kwame Nkrumah University of Science and Technology, Kumasi, Ghana. The lifting period is time when planting of stumps is delayed. A $3 x 5$ split-plot factorial experiment in randomized complete block design was used. The main aim was to determine suitable methods of converting teak seedlings into stumps and evaluate the consequences of delaying planting of teak stumps to enhance high amount of teak shoot production thus address the persistent problem of poor sprouting and low biomass productivity in the early stages of planted teak in large-scale plantation development in Ghana. Collar diameter of stumps, and time as well as the interaction of collar diameter and period of delay of planting stumps and the combined effects of these factors had significant effect on number of shoots per plot. The highest number of teak shoots was obtained from teak stumps of collar diameter of $2.75 \mathrm{~cm}$ planted immediately after harvesting. For teak stumps of collar diameter of $2.75 \mathrm{~cm}$ if planting is delayed for 4 weeks the number of shoots reduces to $25 \%$ of its value if planted immediately. Teak stumps stored in the open air when planting is delayed beyond 15 weeks may not produce shoots.
\end{abstract}

Keywords: Teak, stumps, collar diameter, lifting period, shoot biomass production

\section{INTRODUCTION}

Teak (Tectona grandis) a valuable timber is a large deciduous tree of the family of Verbenaceae. Teak thrives well in Ghana and has been extensively planted in Ghana as an exotic tree species, in the moist and dry semi-deciduous forests and the savannah woodlands. Teak is used extensively for timber, electricity and telephone poles, fuelwood and other products.

The establishment of teak plantations relies mainly on the use of teak stumps as planting materials. These stumps are obtained from pruning the upper stem portion and also roots of bare-rooted seedlings raised on seed beds (Smith, 1986).These stumps are examples of hardwood stem cutting planting materials. Hardwood stem cutting is one of the low cost means of large-scale plant propagation (Erez and Yablowitz, 1981). Stumps are also cheap to prepare, not easily perishable and can be transported over long distances (Hartman et al., 


\section{$22 \quad$ Nkyi et al.}

1993). However, in most cases transport difficulties and other handling problems can delay the planting of teak. The delay in planting of stumps can also be caused by acute shortage of labour at the peak of planting of agricultural crops particularly during weekends, taboo days and funeral festival periods. Usually, the size of teak stumps planted in Ghana range between 0.5 to $5.0 \mathrm{~cm}$ collar diameter, even though its' effects on growth has not been well established.

Several studies have indicated that the sprouting and growth of stem cuttings are influenced by large number of interacting factors forming complex relationships. The rooting ability of hardwood stumps depends on the carbohydrates stored within their tissues (Leakey, 2004) which are also positively correlated with the size of cuttings (Boateng et al., 2003). The delay in lifting plant stocks for planting is injurious to good sprouting and growth of stumps due to the stumps not being able to capture soil mineral water and nutrients for enhanced photosynthesis and growth (Jenkinson, 1980). The sole dependence of these live stumps on their carbohydrates reserves for respiration and maintenance imply that the net carbohydrates within their tissues decrease over time without replenishment, which subsequently reduce their rooting ability and growth.

Low transplanting success and survival of stumps is also due to excessive desiccation during period between harvesting of stumps and planting period (Hartman et al., 1997). There are physiological differences in desiccation tolerance between species which affect the life span of these stumps. Other important factors also affect net water balance in stem cuttings between harvesting and planting period including transpiration rate, air temperature, sunlight intensity, relative humidity and degree of stump lignification (Hartman et al., 1997; Englert et al., 1993). The net water balance in stumps stored in the open air therefore decreases over time. The determination of the extent of dependence of shoot biomass production and growth of teak stumps on seedling collar di- ameter, lifting period and their joint effect is crucial for the success of the plantation program in Ghana, especially for fuelwood, checking erosion in hilly areas and other environmental amelioration programs for which scanty information exist. The evaluation of the nature of the relationship between shoot biomass growth and period of delay of planting of teak stumps help determine the extent to which delay in planting of uprooted and pruned teak seedlings can affect their survival and growth performance for specific seedling sizes.

The main goal of this study is to contribute to the assessment of reduction in growth performance of teak stumps when there is delay in lifting and planting of the stumps and also the extent to which the loss in growth performance is affected by stump collar diameter. The specific objectives of the study were to investigate the dependence of the quantity of shoot biomass of teak stumps on root collar diameter and period of delay in planting and determine the initial trends in the number of shoots per plot over time.

\section{MATERIALS AND METHODS \\ Study Area}

The study was carried out at the demonstration farm of the Faculty of Renewable Natural Resources of Kwame Nkrumah University of Science and Technology (KNUST), Kumasi. The area is located within the Moist Semideciduous South-east Subtype forest zone (Hall and Swaine,1981). The farm lies on longitude $06^{\circ} 43^{\prime} \mathrm{N}$ and latitude $01^{\circ} 36^{\prime} \mathrm{W}$. The mean annual rainfall ranges between $1300 \mathrm{~mm}$ and $1600 \mathrm{~mm}$ while the mean daily temperature ranges between $22.0^{\circ} \mathrm{C}$ and $31.1^{\circ} \mathrm{C}$ (Hall and Swaine,1981). The soils belong to the Asuasi series, classified as forest Ochrosols (SarkodieAddo et al., 2006).

\section{Preparation and transplanting of planting materials}

Three hundred six-month old teak seedlings with root collar diameters in a category of 0.75 $\mathrm{cm}, 1.5 \mathrm{~cm}$ and $2.75 \mathrm{~cm}$ were obtained from a 
watered seed bed of a nursery. The seedlings were then cut at a constant height of $10 \mathrm{~cm}$ above root collar using a sharp medium-sized cutlass and a one-meter ruler. Two rectangular blocks each containing 15 plots were used. On each plot 10 teak stumps were transplanted at a spacing of $30 \times 30 \mathrm{~cm}$.

\section{Experimental Design}

The randomised complete block design (RCBD) in a factorial split-plot experiment was used. The main plot factors were collar diameter of seedling stumps (D) and period of delay in planting or lifting period $(\mathrm{P})$. Time of data collection (T) was used as sub-plot factor. The collar diameters of seedling stumps were 0.75 $\mathrm{cm}\left(\mathrm{D}_{1}\right), 1.5 \mathrm{~cm}\left(\mathrm{D}_{2}\right)$ and $2.75 \mathrm{~cm}\left(\mathrm{D}_{3}\right)$. The periods of delay in planting $(\mathrm{P})$ were 0 weeks $\left(\mathrm{P}_{1}\right), 1$ week $\left(\mathrm{P}_{2}\right), 2$ weeks $\left(\mathrm{P}_{3}\right), 3$ weeks $\left(\mathrm{P}_{4}\right)$ and 4 weeks $\left(\mathrm{P}_{5}\right)$. To mimic the usual storage practices by tree planters in Ghana, the stumps were stored under the shade of scattered trees and covered slightly with some dead leaves before planting, except for immediate planting $\left(\mathrm{P}_{1}\right)$. The number of shoots on sprouted stumps per plot were obtained and used as shoots biomass.

\section{DATA ANALYSIS}

SAS was used. Comparisons of means were based on Duncan's multiple range test ( $p$ $\leq 0.05)$.

\section{RESULTS}

Number of teak shoots according to diameter and lifting period

The mean number of shoots per plot for various stump diameters and lifting periods is shown in Table 1. The mean number of shoots for each of the 15 treatment combinations was calculated over 2 blocks and 8 weeks values. Stumps of collar diameter of $2.75 \mathrm{~cm}$ had the highest mean number of shoots per plot of 27.0 as compared to other stumps of different collar diameters. Also stumps planted on the same day of uprooting yielded the highest mean number of shoots per plot of 25.7 , even though the period of delay in planting was marginally significant at $p<0.1$. Stumps of collar diameter of $2.75 \mathrm{~cm}$ and planted immediately after harvesting had the largest number of shoots per plot of 33.8.

The mean number of shoots per plot follows a linear relation with stump collar diameter with coefficient of correlation $\left(\mathrm{R}^{2}\right)$ being $99.8 \%$ (Fig. 1).

\section{Statistical analysis (ANOVA)}

The analysis of variance (ANOVA) of split-plot experiment in randomized complete block design with collar diameter of stump (D) and period of delay in planting $(\mathrm{P})$ as the main-plot factors and time (T) o f assessment as sub-plot factor was used. The response variable measured for each plot was the number of shoots per

Table 1: Comparisons of number of teak shoots per plot for different stump diameters and lifting periods

\begin{tabular}{lllll}
\hline & \multicolumn{2}{l}{ Collar diameter (D) } & \multicolumn{1}{c}{$\begin{array}{l}\text { Mean of P } \\
\text { treatments }\end{array}$} \\
Period of delay in planting & $\begin{array}{l}\mathbf{0 . 7 5} \mathbf{~ c m} \\
\left(\mathbf{D}_{\mathbf{1}}\right)\end{array}$ & $\begin{array}{l}\mathbf{1 . 5} \mathbf{~ c m} \\
\left(\mathbf{D}_{\mathbf{2}}\right)\end{array}$ & $\begin{array}{l}\mathbf{2 . 7 5} \mathbf{~ c m} \\
\left(\mathbf{D}_{\mathbf{3}}\right)\end{array}$ & \\
\hline 0 weeks $\left(\mathrm{P}_{1}\right)$ & $22.5^{\mathrm{abc}}$ & $20.9^{\mathrm{ab}}$ & $33.8^{\mathrm{de}}$ & $25.7^{\mathrm{q}}$ \\
1 week $\left(\mathrm{P}_{2}\right)$ & $18.3^{\mathrm{ab}}$ & $23.4^{\mathrm{bc}}$ & $29.4^{\mathrm{bcd}}$ & $23.7^{\mathrm{q}}$ \\
2 weeks $\left(\mathrm{P}_{3}\right)$ & $16.4^{\mathrm{a}}$ & $23.1^{\mathrm{bc}}$ & $22.6^{\mathrm{abc}}$ & $20.7^{\mathrm{q}}$ \\
3 weeks $\left(\mathrm{P}_{4}\right)$ & $18.1^{\mathrm{ab}}$ & $21.4^{\mathrm{ab}}$ & $24.0^{\mathrm{bc}}$ & $21.2^{\mathrm{q}}$ \\
4 weeks $\left(\mathrm{P}_{5}\right)$ & $18.2^{\mathrm{ab}}$ & $19.9^{\mathrm{ab}}$ & $25.4^{\mathrm{bc}}$ & $21.1^{\mathrm{q}}$ \\
Mean of D treatments & $18.7^{\mathrm{x}}$ & $21.8^{\mathrm{y}}$ & $27.0^{\mathrm{z}}$ & \\
\hline
\end{tabular}

Letters $x, y$ and $z$ have been used to compare column means; letter q have been used to compare row means. Also letters a, $b, c, d$ and $e$ have been used to compare collar diameter and period of lifting of stumps cell means. 


\section{$24 \quad$ Nkyi et al.}

plot at the end of every week over a period of eight weeks.

The analysis of variance of the experiment on number of shoots per plot is indicated in Table 2. The ANOVA shows that apart from the block and lifting period effects which were not significant at $\mathrm{p}<0.05$, all the other factors: collar diameter, lifting period and collar diameter interaction and time of data collection and also all the two factors and their interaction with time were significant for shoots. However, lifting period was marginally significant $(p<0.1)$. Therefore time, collar diameter and lifting pe-

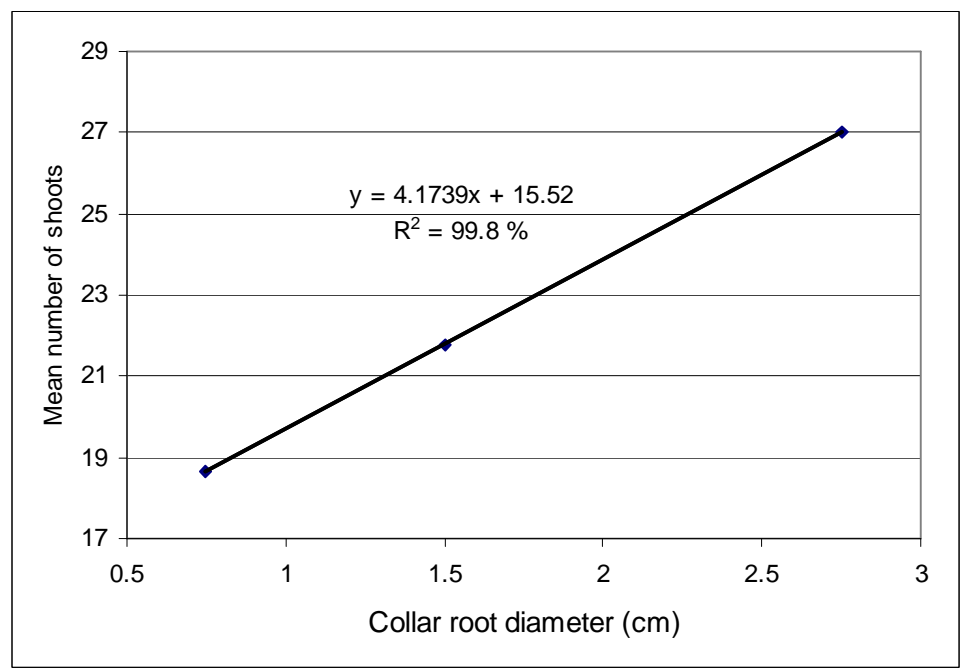

Fig. 1: Effect of collar diameter on mean number of shoots on teak stumps

Table 2: Analysis of variance for number of shoots per plot

\begin{tabular}{|c|c|c|c|c|}
\hline $\begin{array}{l}\text { Sources of } \\
\text { Variation }\end{array}$ & $\begin{array}{l}\text { Sum of } \\
\text { Squares }\end{array}$ & $\begin{array}{l}\text { Degrees of } \\
\text { Freedom }\end{array}$ & $\begin{array}{l}\text { Mean sum } \\
\text { of squares }\end{array}$ & F-ratio \\
\hline Blocks & 22.207 & 1 & 22.207 & $0.285 \mathrm{~ns}$ \\
\hline Period (P) & 902.794 & 4 & 225.699 & $2.902 \mathrm{~ns}$ \\
\hline Diameter (D) & 2844.361 & 2 & 1422.180 & $18.284 * * *$ \\
\hline PD interaction & 890.681 & 8 & 579.729 & $7.453 *$ \\
\hline Error (a) & 1088.981 & 14 & 77.784 & \\
\hline Whole plot & 5749.023 & 29 & & \\
\hline Time $(\mathrm{T})$ & 1428.598 & 7 & 204.085 & $37.839 * * *$ \\
\hline PT interaction & 395.006 & 28 & 97.371 & $18.054 * * *$ \\
\hline DT interaction & 373.439 & 14 & 331.886 & $61.535 * * *$ \\
\hline PDT interaction & 261.519 & 56 & 126.721 & $23.495 * * *$ \\
\hline Error (b) & 566.313 & 105 & 5.393 & \\
\hline Total & 8773.898 & 239 & & \\
\hline
\end{tabular}

Journal of Science and Technology @ KNUST December 2011 
riod and collar diameter interaction are very important factors influencing the shoot biomass production of teak stumps.

Interdependence of number of shoots, lifting period and collar diameter

Figure 2 shows the mean number of shoots per plot as affected by lifting period and collar diameter. The mean number of shoots per plot was highest for stumps of collar diameter of $2.75 \mathrm{~cm}$ and lowest for stumps of collar diameter of $0.75 \mathrm{~cm}$ over all periods of storage of stumps. Collar diameter is linearly related to the number of shoots per plot with a negative slope for stumps of both collar diameter of 0.75 $\mathrm{cm}$ and $2.75 \mathrm{~cm}$. However, the relationship between period of storage and mean number of shoot per plot for stumps of collar diameter of $1.5 \mathrm{~cm}$ is quadratic and after 1.7 weeks of storage of stumps the number of shoot per plot decreases.

\section{Trend analysis}

The relationship between the mean number of shoots per plot and time over an eight-week period is shown by the equation: $y=\frac{x}{0.0061 x^{2}+0.0019 x+0.0492} ;$

$\mathrm{R}^{2}=57.02 \%$ and $\mathrm{p}<0.05$

Equation (1) is an example of the reciprocal model (Mead et al., 1993) with an optimal level

and of a general form of $y=\frac{x}{k_{o}+k_{1} x+k_{2} x^{2}}$

where $k_{o}, k_{1}$ and $k_{2}$ are constants was the best relationship for fitting the mean number of shoots per plot and time.

Figure 3 shows the models for the trend of mean shoots per plot for the time of assessment for the three collar diameters of planted teak stumps. The reciprocal model with an optimal level is excellent in fitting the response curves with $\mathrm{R}^{2}$ ranging between $48.71 \%$ and $59.42 \%$. The model for stumps with collar diameter of $2.75 \mathrm{~cm}$ peaks with the earliest time of 2.7 weeks with the highest mean maximum value of 36 shoots per plot. Also, the model for stumps with collar diameter of $0.75 \mathrm{~cm}$ peaks with the latest time of 3.2 weeks with the lowest mean maximum value of 21.7 shoots per plot.

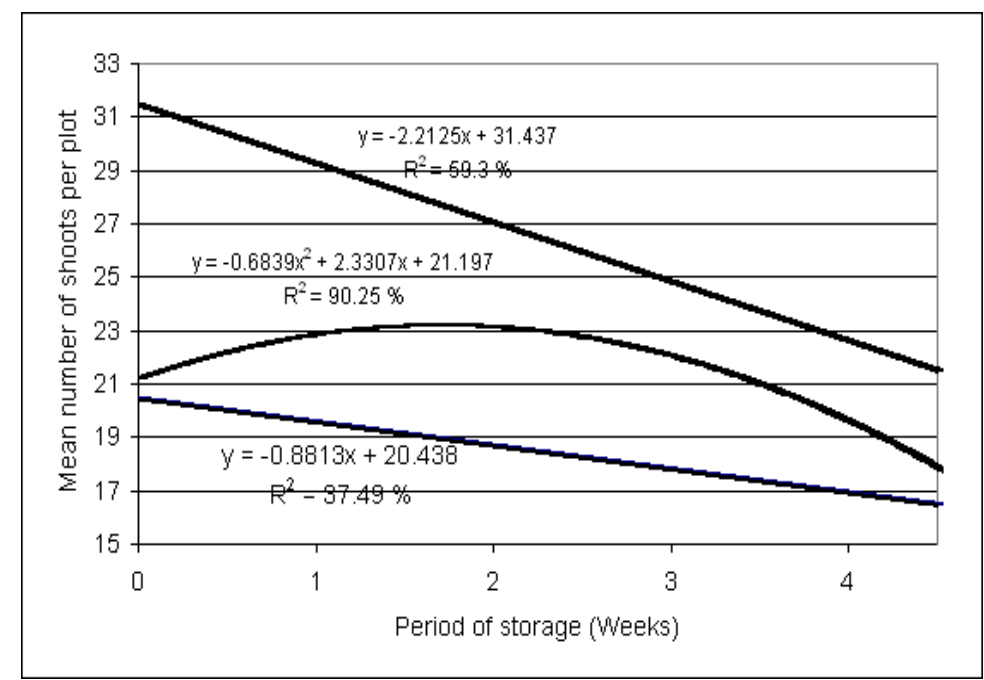

Fig. 2: Relationship between period of storage and mean number of shoots per plot for teak stumps of various collar diameters (D1, D2 and D3) 


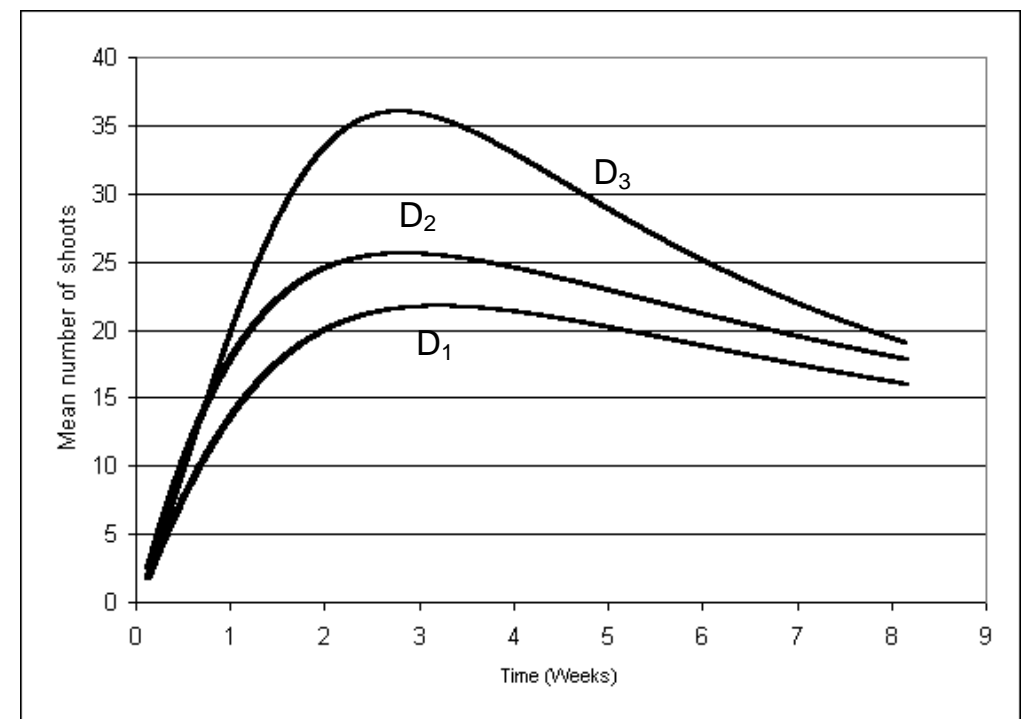

Fig. 3: Mean number of shoots on teak stumps per plot over time as affected by collar diameter $(D)$.

Figure 4 shows the trend of mean number of shoots per plot with time for the five periods of delay in planting of teak stumps. The reciprocal model with an optimal level is also very good in fitting the response curves. The model fittings were suitable to the data with $\mathrm{R}^{2}$ values of the models fit of the curves ranging between $54.28 \%$ and $73.88 \%$. The peak levels of maximum mean number of shoots per plot decrease linearly with increasing period of delay in planting. The respective number of shoots per plot for immediate, 1 week, 2 weeks, 3 weeks and 4 weeks of delay in planting were 32.2 , 30.1, 27.4, 24.7 and 24.2. The resultant model for predicting the maximum number of shoots per plot (y) from period of delay in planting $(\mathbf{P})$ is $\mathbf{y}=31.988-2.1325 \mathbf{P}$

where $\mathrm{R}^{2}=96.62 \%$ and $\mathrm{p}<0.05$

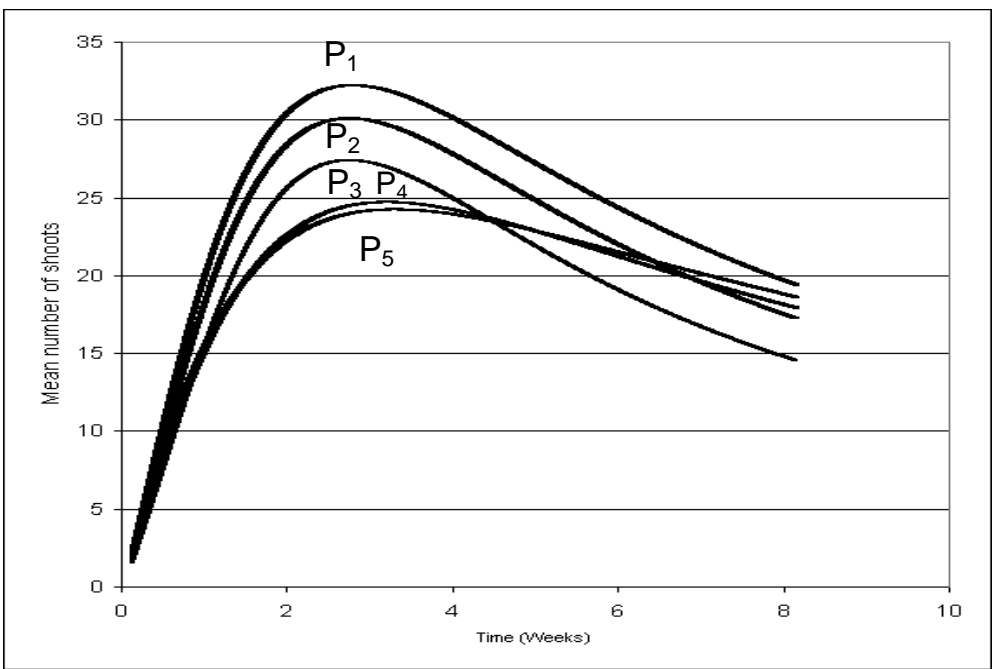

Fig. 4: Mean number of shoots on teak stumps for various periods (P) of storage during planting of the stumps over eight weeks 
From Equation (2) when the storage period is 15 weeks, there is no biomass shoot production.

\section{DISCUSSION}

The quantity of photosynthate, principally in the form of carbohydrate reserves, in a stump exerts great influence in the propagation of the stump and the subsequent shoots biomass production (Boateng et al., 2003). Carbohydrates reserves are positively correlated with the size of cuttings (Boateng et al., 2003). Thus small stumps have insufficient carbohydrate reserves needed to enhance sprouting and nourish developing shoots and roots. Therefore, the relatively high number of shoots for stumps of collar diameter $2.75 \mathrm{~cm}$ could be due to large amount of carbohydrate reserves (Table 1 and Fig. 1).

Respiration rate per gram of dry matter decreases linearly with increasing degree of stump lignification or level of woodiness of the stumps (Leakey, 2004). The decrease in respiration is due to the presence of high amount of non-respiring lignified tissues with low presence of nitrogen. Carbohydrate has less influence on sprouting and rooting of the stumps than nitrogen as reported by Hartman et al., (1993). Therefore, small-sized stumps of 0.75 $\mathrm{cm}$ collar diameter have greater overall rate of respiration than large-sized stumps of $2.75 \mathrm{~cm}$ collar diameter (Leakey, 2004). Thus smallsized stumps have smaller net positive carbon balance than large-sized stumps (Leakey, 2004). The trend is reflected in the significantly higher number of shoots per plot for large-sized stumps than for smaller stumps. The results from the study also conform to observations from several studies (Limpiyaprapant et al., 1996; Wang et al., 1997; and Palanisamy and Kumar, 1997).

If stumps are not planted early they progressively deplete their carbohydrate reserves over time due to maintenance and respiration. According to Hartman et al. (1993), for a specific species, effective storage of seedling cuttings varies from few days to several months. Successful storage of seedling cuttings is directly proportional to the cuttings' carbohydrate reserves and the degree of lignification or the amount of woodiness also correlates positively with collar diameter of the stumps (Hartman $e t$ al., 1993). Consequently, for a specific species such as teak larger stumps of collar diameter of $2.75 \mathrm{~cm}$ have longer successful storage duration and will produce higher shoots biomass than stumps with smaller collar diameter of $0.75 \mathrm{~cm}$ (Fig. 3).

The reduction of ability of stumps to produce appreciable amount of biomass due to delay in planting is of much concern to tree growers. The period of delay in planting of stumps may affect cutting quality by reducing rooting capacity (Hartman et al., 1993). Smith (1986) also observed that stumps quickly lose capacity to root when planting of the stumps is delayed due to squandering of water and carbohydrates especially when the air is dry and warm. The results in Table 1 and Fig. 1 in which teak stumps stored for longer period produce lower number of shoots conform to Hartman et al. (1993)'s observation. According to Hartman et al. (1993), low survival of stumps is due mainly to excessive desiccation during post-production handling. Other important factors which cause deterioration in the capability of stumps for various collar diameters to produce shoots in the tropics include high air temperatures, high irradiance and low relative humidity (Hartman et al., 1993). These factors combine to cause dewilting of the stumps stored in open air with thin debris cover over several weeks. For instance, cuttings which have not rooted are particularly vulnerable to water stress since rehydration of the tissues is very difficult (Hartman et al., 1993). Cuttings which are affected by drought due to delay in planting are also prone to pathogen attacks, disease and pest problems leading to reduction in rooting and subsequently low production of shoot biomass (Rajagopal and Andersen, 1980).

One of the important reasons hampering the rooting and shoot biomass production of stumps when the stumps are not planted early is 
also lack of supply of essential soil resources including dissolved salts, carbon dioxide, mineral elements and water needed to produce high amounts of photosynthates to increase carbohydrates reserves in the stumps over time (Hartman et al., 1993).

Several studies have reported periods of species -specific successful storage of cuttings. Davis and Portter (1985) observed that Rhododendron catawbiense cuttings stored for 21 days at $21^{\circ}$ $\mathrm{C}$ when planted had successful rooting. Also Codiaeum variegatum cuttings stored for 15 days at $20^{\circ} \mathrm{C}$ when planted also had good rooting (Wang, 1987). The results of this work also show that teak stumps stored in the open air when planting is delayed for 15 weeks produce roots but beyond this period the stumps may not produce shoots.

\section{CONCLUSIONS}

Collar diameter of teak stumps significantly affects shoots production, with a strong linear positive relationship as a result of higher carbohydrate reserves in larger stumps. The period of delay in planting interacting with collar diameter result in much variation in the number of shoots per plot. For specific stump collar diameter, there is a progressive decrease in number of shoots as period of delay in planting of teak stumps increases until after 15 weeks when shoots production becomes zero. The consistent reduction of number of shoots of the stumps is due mainly to loss of water, depletion of carbohydrate reserves and pathogen and disease attacks. The ideal strategy for teak plantation establishment is planting teak stumps of collar diameter of about $2.75 \mathrm{~cm}$ immediately after uprooting and pruning the seedlings.

\section{ACKNOWLEDGEMENTS}

Thanks to the Forest Services Division of Forestry Commission of Ghana for providing teak seeds for the nursery from which seedlings were obtained for the experiment. We are also grateful to the Faculty of Renewable Natural Resources, Kwame Nkrumah University of Science and Technology, Kumasi, Ghana for providing land and support. We appreciate the assistance of field measurements of the work by Mr Joseph Owusu.

\section{REFERENCES}

Boateng, P. Y., Asare, C. M. and Adjei, P. Y. (2003). Effect of length and mode of setting of cuttings on the sprouting and seedling development of black pepper (Piper nigrum L.) vines, Ghana Journal of Horticulture, 2: $45-49$.

Cui, Z. L. (1997). Effect of cutting length on rooting and growth of two-year old plantlets of Larix kaempferi in the nursery. Research Institute of Forestry, Beijing, ChinaForest Research, 10 (6): 659-662.

Davis, T. D. and Portter, T. R. (1985). Carbohy -drates, water potential and subsequent rooting of stored rhododendron cuttings. HortScience, 20: 292 - 293.

Englert, J. M., Fuchigami, L. H. and Chen, T. H. H. (1993). Bare-root basics - how to handle bare-root trees and shrubs after harvesting. American Nursery 177 (4): 56 61.

Erez, A. and Yablowitz, Z. (1981). Rooting of peach hardwood cuttings for the meadow orchard, Scientia Horticulture, Vol. 15, pp. 137-144.

Hall, J. B. and Swaine, M. D. (1981). Distribution and ecology of vascular plants in a tropical rain forest - Forest vegetation in Ghana, Dr. W. Junk Publishers, London, $355 \mathrm{pp}$.

Hartmann, H. T., Kester, D. E., Davis, F., Jr., and Geneve, R. L. (1997). Plant propagation $6^{\text {th }}$ Edition, Prentice Hall, New Jersey.

Jenkinson, J. L. (1980). Improving plantation establishment by optimizing growth capacity and planting time of western yellow pines. USFS Res. Paper PSW0154. 22 pp. 
Leakey, R. R. B. (2004). Physiology of vegetative reproduction, in Encyclopaedia of Forest Science, edited by J. Burley, J. Evans, and J. A. Youngquist, Academic Press, U. K, pp.1655-1668.

Limpiyaprapant, S., Soonhuae, P., Kijkar, S. (1996). Rooting ability of Khaya senegalensis cuttings in relation to hedge height and hormone application, Technical Publication ASEAN Forest Tree Seed Centre Project, Thailand, No.33, pp. 1-12.

Mead, R., Curnow, R. N. and Hasted, A. M. (1993).Statistical methods in agriculture and experimental biology, $2^{\text {nd }}$ E d i t i o n, Chapman and Hall, London, pp. 415.

Wang, Y. T. (1987). Effect of temperature, duration and light during simulated shipping on quality and rooting of croton cut- tings; HortScience 22: 1301 - 1302.

Palanisamy, K. and Kumar, P. (1997). Effect of position, size of cuttings and environmental factors on adventitious rooting in neem (Azadirachta indica A. Juss), Forest Ecology and Management, 98: 277-280.

Rajagopal, V. and Adersen, A. S. (1980). Water stress and root formation in pea cuttings. Physiology Plant 48:144 -149.

Sarkodie-Addo, H. K., Adu-Dapaah, N.,EwusiMensah, N and Asare, E. (2006) Evaluation of medium-maturing soya $b$ e a n s (Glycine max (L) Merrill) lines for their nitrogen fixation potentials, Journal of Science and Technology, 26 (2):34-39.

Smith, D. M. 1986). The practice of silviculture. $8^{\text {th }}$ Edition, John Williey and Sons, New York. 